The Geneva Papers on Risk and Insurance, 21 (No. 81, October 1996) 554-556

\title{
Partial Retirement and Public Policy - a Comment
}

\author{
by Peter Scherer*
}

The trend towards early retirement in many OECD countries has come about through an interaction between a policy response to the growth in unemployment which has occurred over the last two decades, and a change in the preferences of many of those nearing retirement age.

The growth in unemployment which has occurred in most OECD governments has often been perceived as signifying a lack of jobs. While in a tautological sense this is true the unemployed are, by definition, people who cannot find a job - in fact the ratio of employment to population has not fallen in most OECD countries over this period. What has occurred has been a change in the structure of employment, with many more adult women entering employment and the proportion of young people in employment falling.

The perception that it was a shortage of jobs which was causing the growth in unemployment resulted in the encouragement of early retirement as way to "free up" posts for young people, enhanced in France by a reduction to age 60 in the standard retirement age itself. In many countries public subsidies have played a part in this: older workers who lose their jobs or who become long term unemployed have become eligible for income support on favourable terms. Sometimes these are explicitly early pensions; sometimes disability benefits awarded on a basis which includes labour market conditions; sometimes they are unemployment or other benefits on special terms: in particular, the job search requirement usually attached to the receipt of unemployment benefits is often relaxed for older workers. Partly in response to these public subsidies, employers - often with the acquiescence of unions - have moved to using early retirement as a preferred way of "downsizing" employment, both in the private and the public sector. Even when employer funded occupational pension funds are used to finance early retirement, this may be preferable - at least in the short run - for an employer to paying redundancy compensation to a younger employee from the regular budget.

The availability of early retirement has led, in turn, to a growing preference for early retirement on the part of employees themselves. This has emerged as pension schemes public and private - have matured and net pensions have started to match net incomes in employment. When early pensions are available on similar terms, this means that there is no

* Head, Social Policy Division, OECD, Paris. The views expressed are the author's and do not engage the OECD. 
net monetary reward to the individual from staying in employment. While early pensions on the same terms as full retirement pensions are rarely available at will, 1 employees who are asked to retire early are unlikely to resist if the terms are generous enough. In some cases, employees may be willing to accept early retirement even if they have to fund it themselves through a reduced pension: this will be the case for individuals who value leisure (or at least dislike their paid occupation) and for whom pension entitlements exceed their needs. ${ }^{2}$

To the extent that this preference for early retirement comes about as a result of the rewards to employment falling to near zero, this is a serious economic distortion. While, as a result of seniority elements in pay schedules, the earnings of older workers may in some cases be greater than the value of their work to the firm, this does not mean that that value is zero, and there is a net economic loss if, because of the incentives provided by pension entitlements, employees who have a continued contribution to offer are encouraged to withdraw prematurely into early retirement. Sociologists have also observed a loss on the part of employees: while they may, given the two alternatives, prefer full retirement to full time employment, the sudden loss of the structure and social context of the work place can often prove emotionally deadening, so that the leisure proves to have less value to the former employee than he or she anticipated.

It is these contradictions in the growth of early retirement which have led to the interest in a "fourth pillar" which will encourage individuals and employers to phase their movement into retirement by going through a phase of partial retirement. Implicitly, these schemes seek to reduce the burden for the employer of the "seniority" element in the wage schedule by having him pay only for part time employment, while the employee receives a supplement which compensates him - fully or partially - for loss of earnings. When implemented as part of the personnel policy of an organisation, this is a progressive and useful way to improve personnel practices, and is certainly preferable to an either/or choice between continued full-time employment and complete retirement.

However, when partial retirement is encouraged by public subsidies, built-in contradictions have been evident. The attractiveness of early retirement is due to the fact that net pension entitlements are close to net earned income, which means that the rate of compensation for earnings loss due to the move to part time employment has to be high. But if it is too high, part-time work will be remunerated at a rate greater than full time work - leading to yet another distortion.

There is however another, more fundamental, problem with these approaches to the problem. The incentives to early retirement which have been discussed above are due in large part to the high returns available from pension schemes. But these returns are themselves under pressure. The movement of the "baby boom" generation into retirement, combined with the reduced mortality of elderly people, mean that public pension systems cannot continue into the future without radical change. These changes will almost certainly

1 Although "seniority" pensions, available to those with a full contribution record, are available before the standard retirement age in Austria and Germany. They have also been available at a very early age in Italy, although this will be changed as a result of the 1995 pension reform in that country.

${ }^{2}$ Evidence that this is the case for some retired people comes from the high rate of household savings amongst the elderly in many countries, and the high rate of intra-family transfers from retired to working age households. 
involve a reduction in the net value of total pension entitlements, probably through a combination of an increase in the age of entitlement for public pensions and a reduction in the pension payable for a given contribution record.

Hence if partial retirement schemes are based on redirecting current public early pension expenditures, they may be making the same sort of mistake as was made when early pensions were introduced to alleviate the growth in unemployment - introducing a form of potentially costly public expenditure to substitute for another which is itself not sustainable.

For these reasons, there may be a case here for thinking more widely. The World Bank has recently suggested that the costs of providing income support to ageing populations could be better managed if provision for future generations of retirees were placed on a capitalised basis, with the earnings of each generation providing the capital base which will fund income support in old age. One of the arguments offered in support of this proposal is that capitalised schemes of this sort will remove the incentive for individuals to retire early and thereby increase their total pension receipts, as the pension entitlements of individuals will be based on retained earnings alone.

Apart from the equity problems involved in the elimination of any "solidarity" 3 element from the main public pension scheme, these proposals face a severe "transition" problem: one generation would continue to have to fund the existing public pension transfers, while simultaneously saving to accumulate a capitalised retirement fund. However, the idea of capitalised schemes could well be envisaged as a means for funding partial retirement. Firms or individuals could supplement their occupational pension funds with supplements specifically dedicated to funding the extra cost of partial retirement. Clearly, any individual contribution would be repayable (with returns to the funds invested) on retirement. If employer funded provision were also payable - at least in part - to an individual who did not choose to participate in partial retirement, it would help to overcome the current problem of choices being made on the basis of maximising pension wealth, rather than to ensure a mutually optimal outcome for employers and the prospective retiree ${ }^{4}$. At the same time, by removing the perceived high cost of retaining workers approaching retirement age, such a policy of advanced funding would be particularly useful in countries such as France, where, according to Guillemard, Walker and Taylor, employers are particularly likely to perceive costs as a barrier to retaining older workers until retirement age.

${ }^{3}$ The World Bank agrees that a social assistance safety net remains necessary for those who fail to qualify for an adequate public pension.

${ }^{4}$ This would seem to be a field in which the insurance industry could take some initiatives. For example, while general unemployment insurance is probably not suited to commercial provision, an insurance element which varied the age at which partial retirement would be offered in the light of economic fluctuations could be explored. 